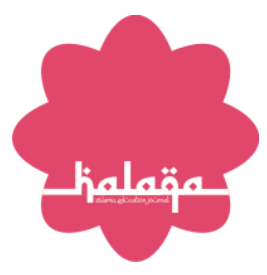

\title{
Math Bilbul "Alaihisalam" as a Learning Innovation During Covid 19
}

\section{Math Bilbul "Alaihisalam” Sebagai Inovasi Pembelajaran Saat Pandemi Covid-19}

\author{
Robia Astuti ${ }^{*}$, Nurmitasari Nurmitasari ${ }^{2}$, Naning Sutriningsih ${ }^{3}$ \\ Fakultas Keguruan dan Ilmu Pendidikan, Universitas Muhammadiyah Pringsewu, Indonesia
}

This research is a research and development that aims to produce an interactive learning media product in the form of an educational game Math BilBul "alaihisalam" (Matematika Bilangan Bulat "ayo belajar operasi hitung secara islam") that is feasible to use and integrates Islamic values and is effective in learning in the era pandemic covid-19. The research subjects were all fourth grade students for the 2020-2021 academic year in the odd semester of SD Muhammadiyah who were at the Sukoharjo Pringsewu branch level. The research method used is development research by adopting the steps of Thiagarajan commonly known as the 4-D development model, namely: Define, Design, Develop, and Disseminate. The data collection technique used is through instruments in the form of learning implementation observation sheets, validation sheets of learning media suitability with student analysis in online learning, student activity observation sheets in learning, student response questionnaires and learning outcomes tests. The results of this study are that an interactive learning media based on the Math BilBul "alaihisalam" educational game has been developed which is considered suitable for use based on the results of expert validation and is considered effective based on the implementation of learning which reaches $100 \%$, student activity reaches $100 \%$, student learning outcomes reach an average value. an average of 90 , which is more than the KKM score, and a positive student response questionnaire that reaches $83.5 \%$.

Keywords: 4-D Development Model, Media, Game, Covid-19, Islam

Penelitian ini merupakan penelitian pengembangan yang bertujuan untuk menghasilkan produk media pembelajaran interaktif berupa game edukasi Math BilBul "alaihisalam" (Matematika Bilangan Bulat "ayo belajar operasi hitung secara islam") yang layak digunakan dan terintegrasi nilai-nilai islam serta efektif dalam pembelajaran di era pandemi covid-19. Subjek penelitian yaitu seluruh siswa kelas IV tahun ajaran 2020-2021 semester ganjil SD Muhammadiyah yang berada di tingkat ranting Sukoharjo Pringsewu. Metode penelitian yang digunakan adalah penelitian pengembangan dengan mengadopsi langkah-langkah Thiagarajan yang biasa dikenal dengan model pengembangan 4-D yaitu: Define, Design, Develop, dan Disse 
-minate Teknik pengumpulan data yang digunakan adalah melalui instrumen berupa lembar observasi keterlaksanaan pembelajaran, lembar validasi kesesuaian media pembelajaran dengan analisis siswa pada pembelajaran daring, lembar observasi aktifitas siswa dalam pembelajaran, angket respon siswa dan tes hasil belajar. Hasil dari penelitian ini yaitu telah dikembangkan media pembelajaran interaktif berbasis game edukasi Math BilBul "alaihisalam" yang dinilai layak digunakan berdasarkan hasil validasi ahli serta dinilai efektif berdasarkan keterlaksanaan pembelajaran yang mencapai $100 \%$, aktivitas siswa mencapai $100 \%$, hasil belajar siswa mencapai nilai rata-rata 90 yaitu lebih dari nilai KKM, dan angket respon positif siswa yang mencapai $83,5 \%$.

Kata Kunci: Pengembangan 4D, Media, Game, Covid-19, Islam 


\section{PENDAHUUAN}

Pandemi covid-19 merupakan wabah yang melanda seluruh belahan dunia, tanpa terkecuali Indonesia. Seluruh aspek kehidupan di Indonesia terkena dampaknya, begitu pula pendidikan. Ada dua dampak bagi keberlangsungan pendidikan yang disebabkan oleh pandemi Covid-19. Pertama adalah dampak jangka pendek, Di Indonesia banyak keluarga yang kurang familier melakukan sekolah di rumah. Bersekolah di rumah bagi keluarga Indonesia adalah kejutan besar khususnya bagi produktivitas orang tua yang biasanya sibuk dengan pekerjaannya di luar rumah. Demikian juga dengan problem psikologis para siswa yang terbiasa belajar bertatap muka langsung dengan guru-guru mereka. Kedua adalah dampak jangka panjang. Dampak pendidikan dari sisi waktu jangka panjang adalah aspek keadilan dan peningkatan ketidaksetaraan antar kelompok masyarakat dan antar daerah di Indonesia. Aji (2020)

Kehadiran wabah Covid-19 yang sangat mendadak memaksa sekolah menggunakan media pembelajaran daring yang membutuhkan teknologi dalam pembelajaran. Namun banyak masalah yang menghambat terlaksananya efektivitas pembelajaran dengan metode daring. Diantaranya adalah (1) Keterbatasan Penguasaan Teknologi Informasi oleh Guru dan Siswa, (2) Sarana dan Prasarana yang Kurang Memadai, (3) Akses Internet yang terbatas, (4) Kurang siapnya penyediaan anggaran Aji (2020). Namun demikian, demi berlangsungnya proses pembelajaran dengan memperhatikan kesehatan para peserta didik pembelajaran daring tetap harus dilaksanakan. Pembelajaran daring adalah pembelajaran yang berlangsung dalam jaringan dimana pengajar dan pelajar tidak bertatap muka secara langsung Albert (2020). Pembelajaran daring memerlukan sebuah media seperti komputer, laptop, atau hp adroid untuk menunjang pembelajaran. Banyak apikasi yang dapat menunjang pembelajaran daring yaitu whatsApp, Zoom, Microsoft team, google meeting, dan masih banyak yang lainnya. Inovasi pembelajaran sangat diperlukan pada pembelajaran daring agar tujuan pembejaran dapat tercapai secara optimal dan mengurangi rasa bosan siswa.

Pembelajaran daring selama ini yang berjalan pada setiap sekolah-sekolah terutama di Sekolah Dasar hanya sebatas mengirimkan file atau foto materi pembelajaran kemudian siswa diberikan tugas yang dikerjakan di rumah masingmasing lewat aplikasi whatsapp grup. Hal ini menjadikan siswa merasa kesulitan dalam memahami materi yang diajarkan dan membuat siswa merasa bosan. Hal ini membutuhkan solusi, sehingganya siswa merasa senang walaupun belajar di rumah, salah satu solusinya yaitu membuat media pembelajaran yang interaktif yang berbentuk game edukasi.

Menurut teori Piaget perkembangan kognitif siswa SD berada pada tahap operasional konkrit yaitu anak sudah cukup matang untuk menggunakan pemikiran logika atau operasi, tetapi hanya untuk objek fisik yang ada saat ini. Ibda (2015). Pada tahap ini penggunaan media pembelajaran interaktif berupa game edukasi seperti Math-bilbul"Alaihisalam” sangat cocok diterapkan pada pelajaran matematika di SD karena Math bilbul "alaihisalam" di desain sesuai dengan tahap perkembangan kognitif siswa SD yang pemahamannya masih pada tahap operasional kongkrit dalam memahami konsep bilangan bulat.

Math-bilbul "Alaihisalam" merupakan media pembelajaran interakif berupa game edukasi pada materi bilangan bulat yang terintegrasi dengan nilai-nilai islam. Media ini membuat siswa SD lebih mudah dalam memahami konsep bilangan bulat dan memahami nilai islam. Bilangan bulat merupakan konsep dasar yang harus dipahami siswa agar mudah mempelajari konsep yang lain. Sedangkan nilai islam pada SD Muhammadiyah khususnya, merupakan konsep dasar agar siswa memiliki akidah dan akhlak yang sesuai dengan syariat islam. Hal ini selaras dengan pernyataan Rojii et al., (2019) bahwa Sekolah Islam seyogyanya harus mampu mengintegrasikan nilai-nilai Islam ke dalam berbagai mata pelajaran non pendidikan agama Islam, bahkan indikator pencapaian belajar siswa tidak hanya diukur dengan tercapainya sebuah kompetensi, akan tetapi ukuran yang lebih ditekankan adalah, sejauh mana siswa dapat berkomitmen terhadap penjagaan nilai-nilai Islam yang telah mereka pelajari.

Keuntungan media game edukasi Math-bilbul "Alaihisalam" adalah siswa dapat dengan mudah memahami konsep bilangan bulat dan sekaligus dapat memahami nilainilai islam dengan harapan dapat menumbuhkan karakter siswa yang sesuai dengan syariat islam. Pembuatan media game edukasi Math-bilbul "Alaihisalam” tergolong mudah, dengan hanya mengandalkan kreatifititas dalam mengolah Microsoft Power Point. Selanjutnya, media Math-bilbul "Alaihisalam" dikembangkan melalui proses validasi ahli, revisi dan uji coba lapangan sehingga penerapan media tersebut dikatakan layak dan efektif untuk digunakan.

\section{METODE}

Penelitian ini dilaksanakan di SD Muhammadiyah yang ada di tingkat ranting Muhammdiyah Sukoharjo Pringsewu dengan subjek penelitian adalah seluruh siswa kelas IV tahun ajaran 2020-2021 semester ganjil. Jenis penelitian ini adalah penelitian pengembangan yang mengacu pada tahap-tahap pengembangan menurut Thiagarajan yang biasa dikenal dengan model pengembangan 4-D Trianto (2009). Model pengembangan 4-D ini terdiri dari empat tahapan yaitu define, design, develop, dan disseminate.

Kegiatan pada Tahap define meliputi analisis awal-akhir, analisis siswa, analisis tugas dan analisis konsep. Kegiatan pada tahap design yaitu penyusunan tes, pemilihan media pembelajaran alternatif, dan pemilihan format. Kegiatan pada tahap develop meliputi penilaian ahli dan uji coba lapangan dengan tujuan untuk menghasilkan media pembelajaran yang layak dan efektif digunakan setelah melalui beberapa proses revisi berdasarkan penilaian ahli dan ujicoba lapangan tersebut. Dan pada tahap disseminate media pembelajaran yang telah layak dan efektif, akan digunakan oleh siswa kelas IV SD Muhammadiyah di tingkat ranting Sukoharjo dan akan diunggah melalui youtube agar dapat digunakan sebagai alternatif media pembelajaran bilangan bulat oleh seluruh guru dan siswa pada umumnya.

Data dalam penelitian ini adalah data kuantitatif dan data kualitatif. Data kuantitatif diperoleh berdasarkan hasil validasi ahli terhadap media game edukasi Math BilBul "alaihisalam" 
yang dianalisis dan dikembangkan untuk memenuhi aspek kualitas valid, dan data yang diperoleh dari hasil pengamatan keterlaksanaan rencana pembelajaran, hasil pengamatan aktivitas siswa, hasil belajar siswa serta hasil respon siswa untuk memenuhi aspek kualitas efektif. Sedangkan data kualitatif didapat berdasarkan saran dan kritik serta tanggapan dari validator yang nantinya digunakan sebagai bahan pengembangan dan pertimbangan dalam merevisi produk.

Instrument dalam penelitian ini terdiri dari: 1) lembar observasi keterlaksanaan rencana pembelajaran, 2) lembar observasi aktivitas siswa, 3) tes hasil belajar dan 4) Angket respon siswa. Keempat instrument tersebut digunakan untuk mengukur keefektifan produk media pembelajaran berupa game edukasi mathbilbul alaihisalam yang dikembangkan. Analisis data yang digunakan yaitu dengan rumus Percentage of agreement atau rumus persentasi.

\section{HASIL DAN PEMBAHASAN}

\section{Hasil Penelitian \\ Tahap 1: Define (Pendefinisian) Hasil analisis awal-akhir}

Hasil analisis awal akhir atau analisis struktur isi kurikulum SD Kelas IV mata pelajaran matematika pokok bahasan bilangan bulat adalah sebagai berikut. Standar kompetensi: 1 . Memahami sifat-sifat operasi hitung bilangan dan penggunaanya dalam pemecahan masalah, Kompetensi dasar: Melakukan operasi hitung bilangan bulat, Materi: (1) Pengertian bilangan bulat., (2) Melakukan operasi penjumlahan dan pengurangan bilangan bulat, (3) Melakukan operasi perkalian dan pembagian bilangan bulat, dan (4) Melakukan operasi hitung campuran.

Pemahaman materi bilangan bulat sangatlah mempengaruhi keberhasilan siswa pada materi-materi lainnya. Operasi perkalian, pembagian, penjumlahan, dan pengurangan pada bilangan bulat menjadi pondasi seorang anak untuk melakukan perhitungan lainnya. Tujuan khusus wali murid menyekolahkan anaknya di SD Muhammadiyah yaitu memiliki karakter yang sesuai dengan nilai-nilai islam.

\section{Hasil analisis awal-akhir}

Hasil analisis siswa yaitu berdasarkan telaah terhadap karakteristik siswa meliputi latar belakang pengetahuan dan perkembangan kognitif siswa. Seperti pada tabel 1.

[Table 1 abaout here.]

\section{Hasil analisis konsep}

Berikut hasil analisis konsep gambar 1.

[Figure 1 abaout here.]

\section{Spesifikasi tujuan Pembalajaran}

Tujuan pembelajaran pada materi bilangan bulat adalah siswa mampu memahami pengertian bilangan bulat, siswa dapat mengoperasikan perhitungan bilangan bulat dan dapat mengaplikasikannya dalam permasalahan sehari-hari yang terintegrasi nilai-nilai islam baik secara ibadah maupun akidah.
Tahap 1: Design (Perencanaan)

Hasil penyusunan instrument penelitian

Berikut penyusunan instrumen penelitian seperti Lembar pengamatan keterlaksanaan pembelajaran tabel 2.

[Table 2 abaout here.]

Lembar pengamatan aktivitas siswa, tabel 3.

[Table 3 abaout here.]

Lembar penilaian ahli (lembar validasi), tabel 4.

[Table 4 abaout here.]

Lembar validasi media berdasarkan aspek keagamaan, tabel 5.

[Table 5 abaout here.]

Lembar validasi Ahli Media Pembelajaran Aspek Tampilan, tabel 6.

[Table 6 abaout here.]

Lembar validasi Ahli Media Pembelajaran Aspek Pemrograman, tabel 7.

\section{[Table 7 abaout here.]}

Lembar validasi ahli media pembelajaran pada Aspek Materi, tabel 8.

[Table 8 abaout here.]

\section{Tes hasil belajar}

Instrument tes hasil belajar dibagikan kepada siswa dengan cara mengirimkan soal melalui google form. Soal pada google form tersebut dapat dilihat pada https://docs.google.com/forms/d/e/1FAIpQLSerJ8knvPL517 s5kDMqIvCm4Pt5ujunvKnLUFMrBeS_rOFHgA/viewform? usp=sf_link.

\section{Angket respon siswa}

Berikut tabek angket respon siswa telah disusun oleh peneliti seperti padatable berikut, tabel 9.

[Table 9 abaout here.]

\section{Hasil penyusunan media pembelajaran}

Berikut tampilan dari media pembelajaran Math BilBul “Alaihisalam" adalah sebagai berikut, gambar 2.

[Figure 2 abaout here.]

\section{Tahap 3: Develop (Pengembangan) Hasil penilian ahli}

Berikut grafik hasil penilaian ahli; grafik penilaian pada aspek keagamaan dan Penilaian Pada Aspek Teknologi Informatika. 
[Figure 2 abaout here.]

[Figure 3 abaout here.]

[Figure 4 abaout here.]

\section{Hasil analisis uji coba \\ Hasil pengamatan keterlaksanaan pembelajaran}

Hasil pengamatan keterlaksanaan pembelajaran yaitu pada saat guru dalam mengelola proses pembelajaran untuk pertemuan 1, 2, dan 3 dapat dilihat pada table berikut, tabel 10.

\section{[Table 10 abaout here.]}

Berdasarkan table tersebut, diperoleh tingkat reliabilitas keterlaksanaan pembelajaran atau RPP adalah sebesar $100 \%$. Hal ini menunjukan bahwa media pembelajaran mathbilbul alaihisalam dinilai efektif berdasarkan pengamatan keterlaksanaan pembelajaran.

\section{Hasil pengamatan aktivitas siswa}

Berdasarkan hasil pengamatan, diperoleh tingkat reliabilitas sebesar $100 \%$. Hal ini menunjukan bahwa media pembelajaran mathbilbul alaihi salam efektif dalam mengaktifkan siswa.

\section{Hasil Belajar}

Tes hasil belajar yang telah direvisi berdasarkan hasil validasi, lalu diujicobakan pada siswa kelas IV SD Muhammadiyah Sukoharjo Pringsewu. Subjek dalam ujicoba ini berjumlah 12 siswa. Data hasil ujicoba tes hasil belajar siswa dapat dilihat pada table berikut, tabel 11.

\section{[Table 11 abaout here.]}

Berdasarkan tabel di atas, rata-rata hasil belajar siswa adalah sebesar 90 yaitu lebih besar dari nilai KKM yaitu 75 . Hal ini menunjukan bahwa media pembelajaran berupa game edukasi math bilbul alaihisalam efektif dalam meningkatkan hasil belajar siswa.

\section{Hasil analisis angket respon siswa}

Rekapitulasi hasil angket respon siswa setelah memperoleh pembelajaran dengan menggunakan media math bilbul alaihisalam dapat dilihat pada table berikut, tabel 12.

\section{[Table 12 abaout here.]}

Berdasarkan table di atas, diperoleh data yaitu 2 siswa memberikan respon negatif dan 10 siswa memberikan respon positif terhadap pembelajaran dengan menggunakan media pembelajaran berbasis game edukasi math bilbul alaihisalam, sehingga tingkat reliabilitas respon siswa adalah sebesar $83 \%$ yang berarti bahwa penggunaan media pembelajaran math bilbul alaihisalam efektif berdasarkan respon siswa.

\section{Pembahasan}

Berdasarkan analisis pada tahap define, diperoleh hasil bahwa materi yang sulit untuk dipahami adalah bilangan bulat. Pemahaman materi bilangan bulat sangatlah mempengaruhi keberhasilan siswa pada materi-materi lainnya. Operasi perkalian, pembagian, penjumlahan, dan pengurangan pada bilangan bulat menjadi pondasi seorang anak untuk melakukan perhitungan lainnya. Tujuan khusus wali murid menyekolahkan anaknya di SD Muhammadiyah yaitu memiliki karakter yang sesuai dengan nilai-nilai islam. Selain itu, diperoleh pula informasi tentang kemampuan anak dalam menyelesaikan soal-soal bilangan bulat belum sesuai harapan. Oleh karena itu, salah satu solusinya yaitu pada tahapan kedua yaitu dengan mendesain suatu media pembelajaran yang sesuai dengan perkembangan kognitif siswa SD yang terintegrasi nilai-nilai islam yaitu media pembelajaran interaktif berbasis game edukatif yang diberi nama MathBilBul "Alaihisalam" (matematika bilangan bulat "ayo belajar operasi hitung secara islam"). Kemudian pemilihan format, Media pembelajaran MathBilBul "Alaihisalam" didesign dalam bentuk game edukatif dengan memadukan antara materi bilangan bulat dengan nilai-nilai islam, dibuat dengan tujuan anak dapat belajar sambil bermain, yang akhirnya anak akan merasa senang dalam mengikuti pembelajaran dan berdampak pada tercapainya tujuan pembelajaran secara optimal. Desain media Mathbilbul "alaihisalam" ini menggunakan power point interaktif atau PPT interaktif yang terdapat menu dan tombol-tombol yang memiliki fungsi berbeda-beda.

Media Mathbilbul Alaihisalam didesain sesuai dengan dengan nilai-nilai islam yang diharapkan dapat diterapkan sehingga selain paham akan bilangan bulat siswa juga memahami nilai-nilai islam yang nantinya akan di terapkan dalam kehidupan sehari-hari. Jempa (2017) menyatakan bahwa nilai-nilai islam pada hakekatnya adalah kumpulan prinsip-prinsip hidup, ajaran-ajaran tentang bagaimana manusia seharusnya menjalankan kehidupan di dunia ini yang satu prinsip dengan yang lainnya saling terkait membentuk satu kesatuan yang utuh tidak dapat dipisah-pisahkan. Kemudian Hakim (2012) nilai - nilai ajaran islam merupakan nilai-nilai yang akan mampu membawa manusia kepada kebahagiaan, kesejahteraan, keselamatan manusia baik dalam kehidupan di dunia maupun di akhirat. Dengan demikian nilai-nilai islam adalah suatu nilai-nilai yang menjadi pedoman hidup manusia dalam menjalani kehidupan di dunia agar bahagia di dunia dan di akhirat nantinya.

Selanjutnya. Pada tahap develop, desain media divalidasi oleh 3 validator atau ahli. Pada aspek materi menunjukkan bahwa kualitas materi baik, hal ini terlihat dari $60 \%$ ahli materi memberikan penilaian baik dan $20 \%$ memberikan penilaian sangat baik. Sehingga jika digabung menjadi $80 \%$. Untuk kualitas bahasa ada sedikit perbaikan, terlihat pada $50 \%$ ahli materi yang memberikan kurang baik. Perbaikan itu adalah bahasa harus disesuaikan dengan sasaran yaitu anak SD kelas IV. Adapun nilai validasi pada aspek materi yaitu sebesar 71,43 yang artinya valid.

Penilaian ahli pada aspek keagamaan menunjukkan bahwa setiap kriteria penilaian bernilai baik. Terlihat pada gambar 10, bahwa untuk kriteria relevansi perolehan penilaian baik sebanyak $50 \%$ dan penilaian sangat baik sebanyak 50\%, untuk kriteria keakuratan perolehan penilaian baik adalah $100 \%$, kriteria konsep dasar materi yaitu perolehan penilaian baik sebanyak $100 \%$ dan kriteria kesesuaian sajian dengan tuntutan pembelajaran yang 
terpusat pada siswa perolehan penilaian baik yaitu $75 \%$ dan penilaian sangat baik yaitu $25 \%$. Untuk itu dari segi keagamaan tida perlu lagi ada perbaikan. Adapun nilai validasi pada aspek keagamaan yaitu sebesar 80,77 yang artinya valid.

Penilaian ahli pada aspek teknologi informatika menunjukkan bahwa setiap kriteria penilaian bernilai baik. Dari gambar 11 diperoleh bahwa untuk kriteria kualitas grafis perolehan penilaian baik sebanyak $67 \%$ dan penilaian sangat baik sebanyak 33\%, untuk kriteria kualitas tombol perolehan penilaian baik adalah $100 \%$, kriteria kualitas media yaitu perolehan penilaian baik sebanyak $25 \%$ dan penilaian sangat baik yaitu $75 \%$ dan kriteria fungsi tombol perolehan penilaian baik penilaian baik yaitu $50 \%$ dan penilaian sangat baik yaitu $50 \%$. Namun ada saran dari ahli teknologi informatika yaitu pemilihan layout, warna dan teks dibuat lebih menarik untuk memudahkan interaksi media dengan pengguna. Adapun nilai validasi pada aspek teknologi informatika yaitu sebesar 85,71 yang artinya valid.

Dari data yang tersaji pada masing-masing aspek penilaian menunjukkan bahwa media pembelajaran sudah valid dan layak digunakan dengan sedikit perbaikan. Untuk itu media pembelajaran MathBilbul "Alaihisalam" direkomendasikan untuk digunakan dalam pembelajaran daring di SD kelas IV. Setelah desain media dinyatakan valid dan layak digunakan, maka dilakukan ujicoba dan diperoleh tingkat reliabilitas keterlaksanaan pembelajaran atau RPP pada saat ujicoba adalah sebesar $100 \%$. Hal ini menunjukan bahwa media pembelajaran mathbilbul alaihisalam dinilai efektif berdasarkan pengamatan keterlaksanaan pembelajaran. Kemudian, tingkat reliabilitas pengamatan aktivitas siswa sebesar $100 \%$. Hal ini menunjukan bahwa media pembelajaran mathbilbul alaihi salam efektif dalam mengaktifkan siswa. Selain itu, diperoleh pula rata-rata hasil belajar siswa sebesar 90 yaitu lebih besar dari nilai KKM yaitu 75. Hal ini menunjukan bahwa media pembelajaran berupa game edukasi math bilbul alaihisalam efektif dalam meningkatkan hasil belajar siswa. Serta berdasarkan respon siswa, diperoleh data yaitu 2 siswa memberikan respon negatif dan 10 siswa memberikan respon positif terhadap pembelajaran dengan menggunakan media pembelajaran berbasis game edukasi math bilbul alaihisalam, sehingga tingkat reliabilitas respon siswa adalah sebesar $83 \%$ yang berarti bahwa penggunaan media pembelajaran math bilbul alaihisalam efektif berdasarkan respon siswa. Berdasarkan tahapan pengembangan yang telah dilaksanakan, maka penelitian ini telah menghasilkan sebuah produk media pembelajaran interaktif berupa game edukasi Mathbilbul Alaihisalam yang layak dan efektif dalam pembelajaran

\section{KESIMPULAN}

Berdasarkan tujuan dan hasil penelitian yang telah diuraikan, diperoleh kesimpulan yaitu dengan menggunakan model pengembangan 4-D, dihasilkan produk berupa media pembelajaran interaktif berbasis game edukasi Math BilBul alaihisalam sebagai inovasi pembelajaran di masa pandemi Covid-19 pada pokok bahasan bilangan bulat di kelas IV SD Muhammadiyah Sukoharjo yang dinilai layak digunakan berdasarkan hasil validasi ahli dari tiga validator yaitu 1 ahli dalam bidang keagamaan,1 ahli dalam bidang pendidikan sekolah dasar, dan 1 ahli dalam bidang teknologi, serta dinilai efektif berdasarkan keterlaksanaan pembelajaran yang mencapai $100 \%$, aktivitas siswa mencapai $100 \%$, hasil belajar siswa mencapai nilai rata-rata 90 yaitu lebih dari nilai KKM, dan angket respon positif siswa yang mencapai 83,5\%.

\section{UCAPAN TERIMA KASIH}

Pada kesempatan ini, kami tim pelaksana penelitian menyampaikan rasa terimakasih dan penghargaan yang sebesar-besarnya kepada berbagai pihak yang telah mendukung, memotivasi, dan mengarahkan kami dalam proses pelaksanaan penelitian ini. Beberapa yang harus penulis sebutkan antara lain: Pertama, terimakasih kami sampaikan kepada Majelis Diktilitbang PP Muhammadiyah yang telah mendanai seluruh kegiatan program Hibah RisetMu Batch 4 ini dan memberikan kesempatan kepada kami untuk mengembangkannya. Kedua, terimakasih penulis sampaikan kepada pihak Universitas Muhammadiyah Pringsewu Lampung (UMPRI) yang selalu mendukung berbagai program pengembangan penelitian; serta mempermudah proses administrative dalam proses pelaksanaan kegiatan. Ketiga, terimakasih penulis sampaikan kepada pihak SD Muhammadiyah Sukoharjo yaitu Miswati, S.Pd (Kepala SD M Sukoharjo) dan seluruh dewan guru yang telah mengizinkan peneliti untuk melaksanakan peneltian ini. Terakhir, penulis sampaikan terimakasih kepada Dra. Noerhasmalina, M.Pd. selaku Ketua Program Studi Pendidikan Matematika dan seluruh rekan dosen program studi pendidikan matematika yang tidak dapat disebutkan satu persatu.Mereka seluruhnya telah menjadi bagian dari proses kegiatan penelitian ini melalui diskusi yang berkelanjutan baik pada saat kegiatan berlangsung maupun di luar kegiatan. Semoga amal baik mereka diterima disisi Allah SWT sebagian dari amal shaleh dan ilmu yang bermanfaat. 


\section{REFERENCES}

Albert Efendi Pohan (2020). Konsep Pembelajaran Daring berbasis pendekatan Ilmiah. Jawa Tengah: CV Sarnu Untung.

Ibda, F. (2015). Perkembangan Kognitif: Teori Jean Piaget. Jurnal Intelektualita, Vol. 3, No. 1.

Lukman Hakim (2012). Internalisasi Nilai-Nilai Agama Islam dalam Pembentukan Sikap dan Perilaku Siswa Sekolah Dasar Islam Terpadu AlMuttaqin Kota Tasik Malaya. Jurnal Pendidikan Agama Islam Ta'lim Vol. 10, No. 1.

Mohamad Rojii, dkk. (2019). Desain Kurikulum Sekolah Islam Terpadu (studi kasus di SMPIT Insan Kamil Sidoarjo). Jurnal Al-Tanzim: Jurnal Manajemen Pendidikan Islam. Vol. 03, No. 02.

Nurul Jempa (2017). Nilai-nilai Agama Islam. Jurnal Ilmiah Pendidikan dan Pembelajaran Fakultas Tarbiah Universitas Muhammadiyah Aceh. Vol. 4, No. 2.

Rizqon Halal Syah Aji.(2020). Dampak Covid-19 pada Pendidikan di Indonesia: Sekolah, Keterampilan, dan Proses Pembelajaran. Jurnal Sosial dan Budaya Syar-i. Vol. 7, No. 5.

Trianto. (2009). Mendesain Model Pembelajaran Inovatif Progresif. Jakarta: kencana prenada media grup.
Conflict of Interest Statement: The authors declare that the research was conducted in the absence of any commercial or financial relationships that could be construed as a potential conflict of interest.

Copyright (C) 2021 Robia Astuti, Nurmitasari Nurmitasari, Naning Sutriningsih. This is an open-access article distributed under the terms of the Creative Commons Attribution License (CC BY). The use, distribution or reproduction in other forums is permitted, provided the origi- nal author(s) and the copyrightowner(s) are credited and that the original publication in this journal is cited, in accordance with accepted academic practice. No use, distri-bution or reproduction is permitted which does not comply with these terms. 


\section{LIST OF TABLES}

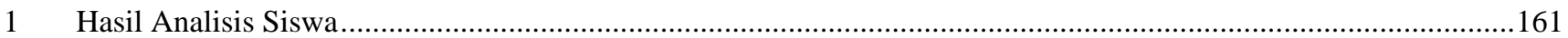

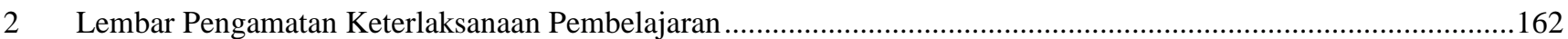

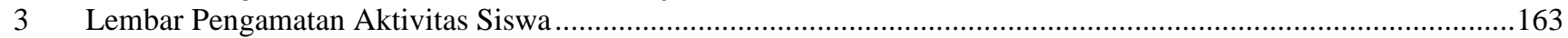

4 Lembar Validasi Media Berdasarkan Aspek Keagamaan .............................................................................164

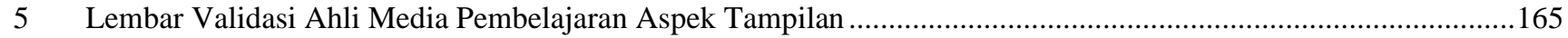

$6 \quad$ Lembar Validasi Ahli Media Pembelajaran Aspek Pemrograman ...............................................................166

7 Lembar Validasi Ahli Media Pembelajaran Pada Aspek Materi ....................................................................167

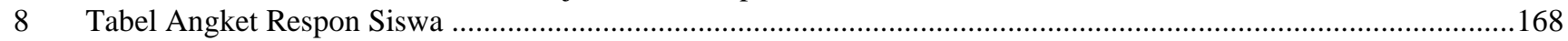

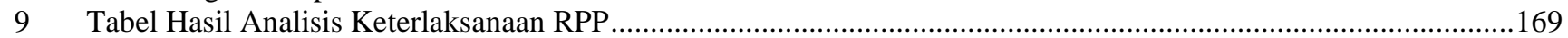

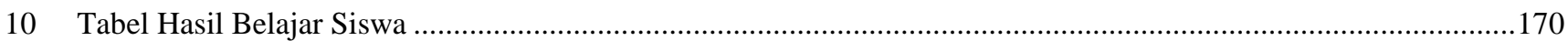

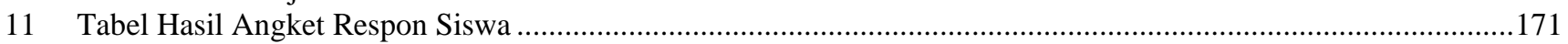


TABLE 1/Hasil Analisis Siswa

\begin{tabular}{|c|c|c|c|}
\hline \multirow[t]{2}{*}{ Kondisi Real Siswa } & \multirow[t]{2}{*}{ Kondisi Ideal } & \multicolumn{2}{|c|}{ Kesenjangan } \\
\hline & & Kuat & Lemah \\
\hline 1. Siswa belum dapat menyebutkan pengertian bilangan bulat & $\begin{array}{l}\text { 1. Siswa dapat menyebutkan pengertian } \\
\text { bilangan bulat }\end{array}$ & $\sqrt{ }$ & \\
\hline $\begin{array}{l}\text { 2. Siswa masih bingung dalam melakukan operasi penjumlahan dan } \\
\text { pengurangan bilangan bulat, terlebih yang terintegrasi nilai-nilai } \\
\text { islam pada kehidupan nyata }\end{array}$ & $\begin{array}{l}\text { 2. Siswa dapat melakukan operasi } \\
\text { penjumlahan bilangan bulat, terlebih yang } \\
\text { terintegrasi nilai-nilai islam pada kehidupan } \\
\text { nyata }\end{array}$ & $\sqrt{ }$ & \\
\hline 3. Siswa belum paham konsep operasi perkalian bilangan bulat & $\begin{array}{l}\text { 3. Siswa belum paham konsep operasi } \\
\text { perkalian bilangan bulat }\end{array}$ & $\sqrt{ }$ & \\
\hline 4. Siswa belum paham konsep operasi pembagian pada bilangan bulat & $\begin{array}{l}\text { 4. Siswa paham konsep operasi pembagian } \\
\text { pada bilangan bulat }\end{array}$ & $\sqrt{ }$ & \\
\hline $\begin{array}{l}\text { 5. Siswa belum dapat melakukan operasi perkalian dan pembagian } \\
\text { bilangan bulat dan belum pernah mengerjakan soal-soal perkalian } \\
\text { dan pembagian yang terintegrasi nilai-nilai islam }\end{array}$ & $\begin{array}{l}\text { 5. Siswa dapat melakukan operasi perkalian } \\
\text { dan pembagian bilangan bulat dan sudah } \\
\text { pernah mengerjakan soal-soal perkalian } \\
\text { dan pembagian yang terintegrasi nilai-nilai } \\
\text { islam }\end{array}$ & $\sqrt{ }$ & \\
\hline $\begin{array}{l}\text { 6. Siswa belum dapat melakukan operasi hitung campuran pada } \\
\text { bilangan bulat yang terintegrasi nilai-nilai islam }\end{array}$ & $\begin{array}{l}\text { 6. Siswa dapat melakukan operasi hitung } \\
\text { campuran pada bilangan bulat yang } \\
\text { terintegrasi nilai-nilai islam }\end{array}$ & $\sqrt{ }$ & \\
\hline
\end{tabular}


TABLE 2 / Lembar Pengamatan Keterlaksanaan Pembelajaran

\section{Langkah-langkah}

Terlaksana

Skor

Kegiatan Awal

Melakukan apersepsi:

Bertanya kepada siswa apakah masih ingat dengan bilangan bulangan? Apa itu bilangan

bulat?

Memotivasi siswa untuk tetap giat dan semangat belajar meskipus di masa pandemi covid

19 ini semua pembelajaran harus daring

Menyampaikan inti tujuan pembelajaran, meliputi produk, proses dan keterampilan social

yang terintegrasi nilai-nilai Islam.

Kegiatan inti

Memperkenalkan kepada siswa tentang media pembelajaran yang akan digunakan, yaitu

PPT interaktif "Math Bilbul Alaihisalam"

Menjelaskan satu persatu fitur yang ada pada media interaktif math bilbul alaihisalam dan

berikan kesan menarik untuk belajar sambil bermain dengan konsep game pada math

bilbul alaihisalam

Menyajikan informasi atau materi tentang pengertian bilangan bulat dan jenis-jenis operasi

aritmatika pada bilangan bulat dengan menggunakan media pembelajaran PPT "Math

bilbul alaihisalam"

Meminta siswa mencoba menggunakan media PPT interaktif Math Bilbul Alaihisalam untuk

meningkatkan keterampilannya dalam menggunakan media pembelajaran.

Membimbing siswa untuk memahami contoh-contoh soal pada operasi aritmatika bilangan

bilat,yang ada pada media math bilbul alaihisalam

Membimbing siswa untuk memainkan game yang ada pada media mathbilbul alaihisalam

yang berisi tentang soal-soal bilangan bulat, dan meminta mereka untuk

menjawab/mengerjakan soal-soal tersebut

Member penghargaan/pujian kepada siswa yang kinerjanya bagus, atau banyak

menjawab benar saat bermain game

Penutup

Meminta siswa mengungkapkan pertanyaan yang belum dipahami

Melibatkan siswa menyimpulkan materi yang telah dipelajari dan memantabkan

pemahaman siswa sesuai tujuan pembelajaran sebagai kegiatan refleksi 
TABLE 3/ Lembar Pengamatan Aktivitas Siswa

\section{Nama}

5
10
20
25

30
Menit Ke
40

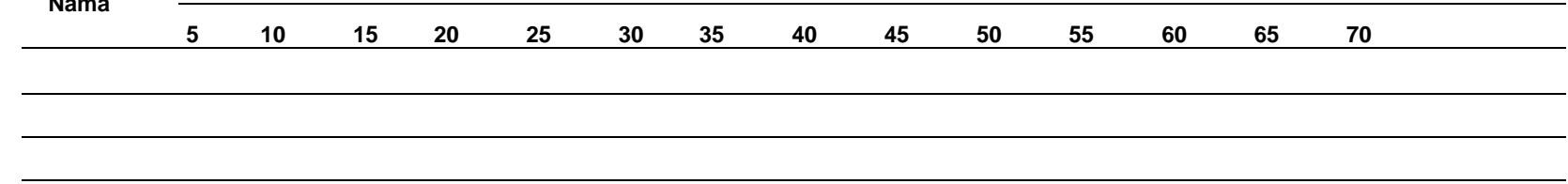

45
50
Ket

Aktivitas:

1. Mendengarkan/memerhatikan penjelasan guru atau siswa secara aktif.

2. Berdiskusi/Tanya jawab antar siswa/guru.

3. Membaca/mengerjakan/menggunakan media pembelajaran yang telah diberikan oleh guru.

4. Menyelesaikan masalah yang diberikan oleh guru secara individu.

5. Bekerjasama dengan siswa lain.

6. Menyampaikan pendapat/ide kepada guru atau teman dalam kelompoknya saat diskusi kelompok

7. Menarik kesimpulan suatu prosedur atau konsep dengan kalimat sendiri

8. Perilaku lain yang tidak relevan dengan kegiatan pembelajaran. 
TABLE 4/ Lembar Validasi Media Berdasarkan Aspek Keagamaan

\begin{tabular}{|c|c|c|c|c|c|c|}
\hline \multirow{2}{*}{ Aspek Penilaian } & \multirow{2}{*}{ Deskripsi } & \multicolumn{5}{|c|}{ SkalaNilai } \\
\hline & & 1 & 2 & 3 & 4 & 5 \\
\hline \multirow[t]{4}{*}{ Relevansi } & $\begin{array}{l}\text { Nilai-nilai islam yang termuat dalam media pembelajaran relevan } \\
\text { dengan kompetensi yang harus dikuasai siswa }\end{array}$ & & & & & \\
\hline & Nilai-nilai islam sesuai dengan tingkat perkembangan siswa SD & & & & & \\
\hline & Nilai-nilai islam sesuai tuntutan kurikulum & & & & & \\
\hline & $\begin{array}{l}\text { Ilustrasi nilai-nilai islam dalam media pembelajaran sesuai dengan } \\
\text { tingkat perkembangan siswa }\end{array}$ & & & & & \\
\hline \multirow[t]{4}{*}{ Keakuratan } & Nilai-nilai islam yang disajikan sesuai dengan kebenaran keilmuan & & & & & \\
\hline & $\begin{array}{l}\text { Nilai-nilai islam yang disajikan sesuai dengan perkembangan } \\
\text { mutakhir }\end{array}$ & & & & & \\
\hline & Nilai-nilai islam yang disajikan sesuai dengan kehidupan sehari-hari & & & & & \\
\hline & $\begin{array}{l}\text { Pengemasan nilai-nilai islam dalam media pembelajaran sesuai } \\
\text { dengan pendekatan keilmuan yang bersangkutan }\end{array}$ & & & & & \\
\hline Materi & Kesesuaian konsep nilai-nilai islam & & & & & \\
\hline \multirow{4}{*}{$\begin{array}{l}\text { Kesesuaian sajian dengan tuntutan } \\
\text { pembelajaran yang terpusat pada siswa }\end{array}$} & Mendorong rasa keingintahuan siswa & & & & & \\
\hline & Mendorong terjadinya interaksi siswa & & & & & \\
\hline & Mendorong siswa membangun pengetahuannya sendiri & & & & & \\
\hline & Mendorong siswa belajar secara kelompok & & & & & \\
\hline
\end{tabular}


TABLE 5/ Lembar Validasi Ahli Media Pembelajaran Aspek Tampilan

Alternatif Pilihan

No

Kriteria

\begin{tabular}{cl}
\hline Kualitas Grafis \\
\hline 1 & Tata letak teks dan gambar pada media pembelajaran \\
2 & Kesesuaian pemilihan background \\
3 & Kesesuaian pemilihan ukuran dan jenis huruf \\
4 & Kesesuaian warna \\
5 & Kemenarikan sajian gambar animasi \\
6 & Kesesuaian pemilihan gambar animasi dengan materi
\end{tabular}

Kualitas Tombol

7

Kemenarikan tampilan tombol

$8 \quad$ Keteraturan dan konsistensi tampilan tombol 
TABLE 6/ Lembar Validasi Ahli Media Pembelajaran Aspek Pemrograman

Alternatif Pilihan

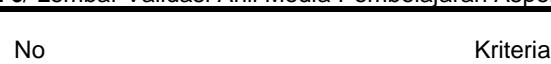

\section{Efisiensi Media}

1 Kemudahan pemakaian program

2 Kemudahan memilih menu program

3 Kemudahan berinteraksi dengan program

$4 \quad$ Kemudahan masuk dan keluar dari program

Fungsi Tombol

5 Kemudahan memahami struktur tombol

$6 \quad$ Ketepatan reaksi tombol 
TABLE 7/ Lembar Validasi Ahli Media Pembelajaran Pada Aspek Materi

\begin{tabular}{clc}
\hline \multicolumn{1}{c}{ No } & \multicolumn{1}{c}{ Kriteria } & Alternatif Pilihan \\
\cline { 2 - 3 } Kualitas & Materi & $\mathbf{2}$ \\
\hline 1 & Tidak ada aspek indicator yang menyimpang & $\mathbf{3}$ \\
2 & Keluasan cakupan isi materi \\
3 & Kejelasan isi materi (berdasarkan indikator) \\
4 & Uraian isi materi \\
\hline Kualitas Bahasa & Kejelasan contoh yang disertakan \\
\hline 5 & Kejelasan bahasa yang digunakan \\
6 & Kesesuaian Bahasa dengan sasaran \\
\hline
\end{tabular}


TABLE 8/ Lembar Tabel Angket Respon Siwa

Skor

$$
\text { Pernyataan }
$$

1

2

Penyajian materi dalam media sistematis dan berurutan sehingga mudah saya pahami

Media pembelajaran "Math Bilbul Alaihisalam" memudahkan saya dalam belajar

Dengan adanya media "Math Bilbul Alaihisalam" ini menambahkan minat saya untuk belajar matematika

materi bilangan bulat

Media "Math Bilbul Alaihisalam" ini dapat menjadi media pembelajaran Matematika mandiri bagi saya

Permasalahan dan persoalan yang disajikan dalam media "Math Bilbul Alaihisalam" merangsang rasa

ingin tahu saya

Bagi saya belajar Matematika (bilangan bulat) menggunakan Media "Math Bilbul Alaihisalam" ini

mengasyikkan

Permasalahan yang disajikan terdapat nilai-nilai islam sehingga meningkatkan pengetahuan keislaman

saya serta meningkatkan keaktifan saya dalam proses pembelajaran

Kemampuan pemecahan masalah dapat membentuk sikap ilmiah saya

Penyajian Media "Math Bilbul Alaihisalam" menarik

Alur ceritanya yang disajikan sesuai dengan taraf berfikir saya dan sesuai dengan kehidupan islami

sehari-hari.

Kejelasan alur cerita yang menarik dan mengarah pada pemahaman konsep

Tingkat artistik dan estetika (keunikan) dalam media menarik sehingga saya termotivasi untuk belajar

Tingkat interaktivitas media menyenangkan dan memikat saya dalam belajar 
TABLE 9/ Hasil Analisis Keterlaksanaan RPP

\begin{tabular}{ccccc}
\hline Pertemuan ke- & Skor yang diperoleh & Skor total & Persentase & Kategori \\
1 & 48 & 48 & $100 \%$ & $100 \% \quad$ terlaksana \\
2 & 48 & 48 & $100 \%$ & terlaksana \\
3 & 48 & 48 & terlaksana \\
\hline
\end{tabular}


TABLE 10/ Hasil Belajar Siswa

\begin{tabular}{|c|c|c|c|}
\hline No & Nama & KKM & Nilai \\
\hline 1 & M. Syafik Ramadhan & & 85 \\
\hline 2 & Khanan Bagus Kurniawan & & 85 \\
\hline 3 & Kiranti & & 80 \\
\hline 4 & Garlanda Arkhan & & 100 \\
\hline 5 & Nirmala Putri Ayundiani & & 100 \\
\hline 6 & Fuad Hafid Zulhilmi & & 100 \\
\hline 7 & Rezky Fajar Ar-Rayan & 75 & 90 \\
\hline 8 & Seziko Sukarja & & 100 \\
\hline 9 & Ukasyah & & 95 \\
\hline 10 & Hana Nur Nadzifa & & 85 \\
\hline 11 & Mayca Nurhasanah & & 80 \\
\hline 12 & Nada Naufa G. & & 80 \\
\hline
\end{tabular}


TABLE 11/ Hasil Angket Respon Siswa

\begin{tabular}{lcccc}
\hline & & & Respon & \\
\cline { 2 - 4 } & Skor & Skor total & Presentase & kategori \\
\hline M. Syafik Ramadhan & 47 & 52 & $90 \%$ & positif \\
Khanan Bagus K & 24 & 52 & $46 \%$ & negatif \\
Kiranti & 40 & 52 & $77 \%$ & positif \\
Garlanda Arkhan & 34 & 52 & $65 \%$ & negatif \\
Nirmala Putri A & 51 & 52 & $98 \%$ & positif \\
Fuad Hafid Zulhilmi & 46 & 52 & $88 \%$ & positif \\
Rezky Fajar A & 47 & 52 & $90 \%$ & positif \\
Seziko Sukarja & 51 & 52 & $98 \%$ & positif \\
Ukasyah & 50 & 52 & $96 \%$ & positif \\
Hana Nur Nadzifa & 47 & 52 & $90 \%$ & positif \\
Mayca Nurhasanah & 46 & 52 & $88 \%$ & positif \\
Nada Naufa G. & 40 & 52 & $77 \%$ & positif \\
\hline
\end{tabular}




\section{LIST OF FIGURE}

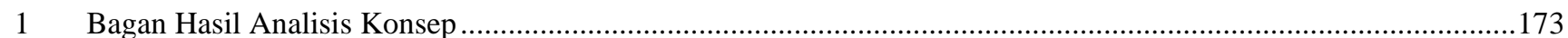

2 Tampilan Media Pembelajaran MathBilBul "Alaihisalam" ..............................................................................174

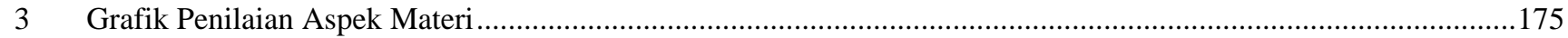

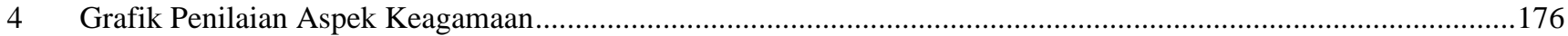

5 Grafik Penilaian Aspek Teknologi Informatika ................................................................................. 177 


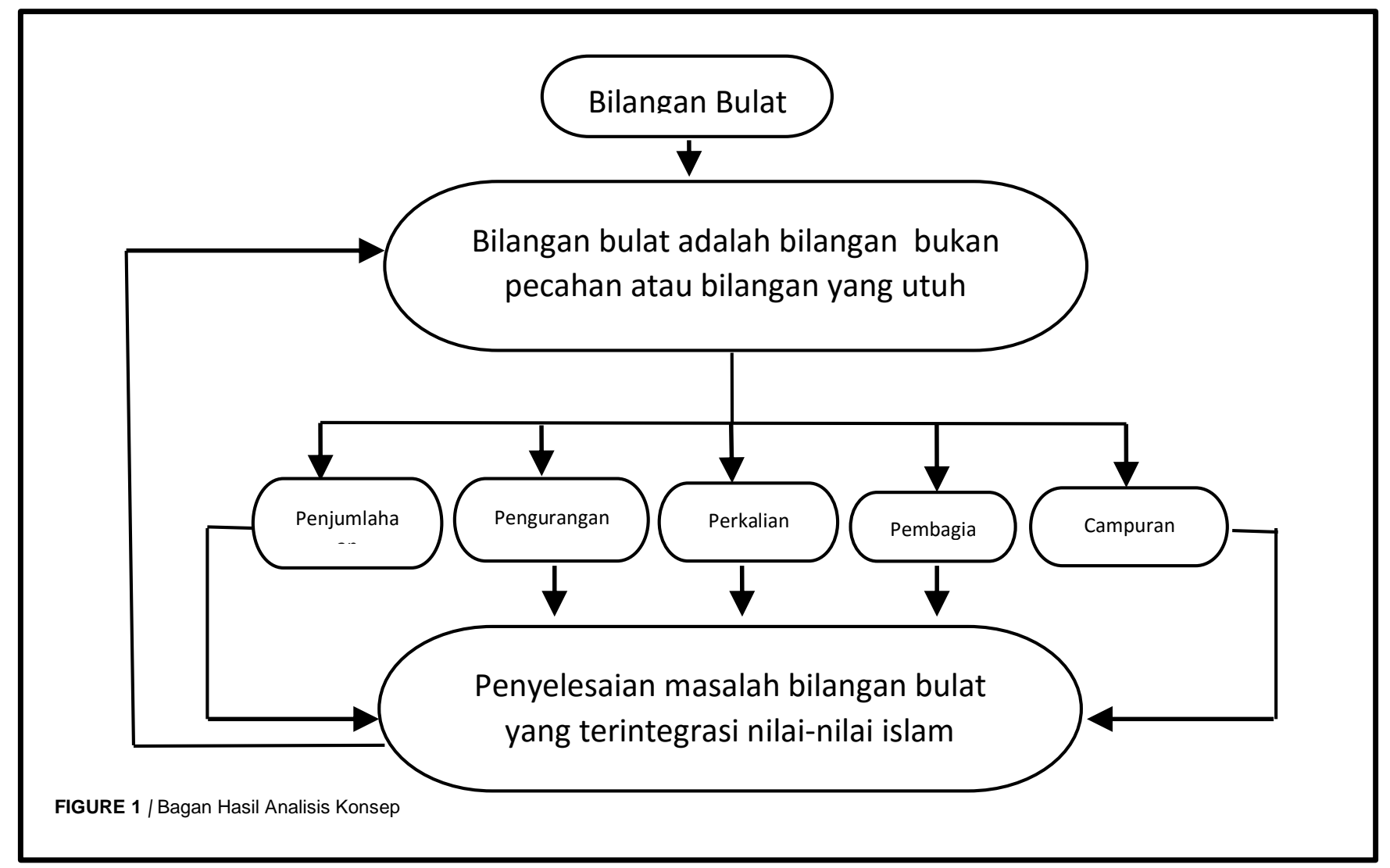




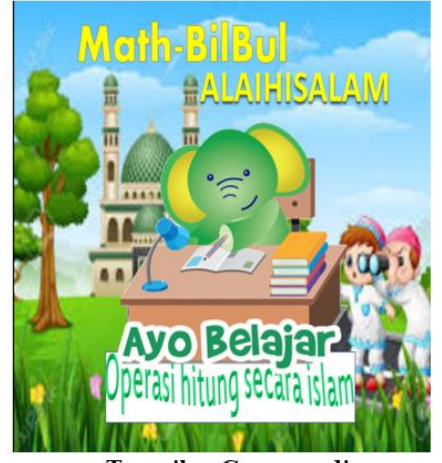

Tampilan Cover media

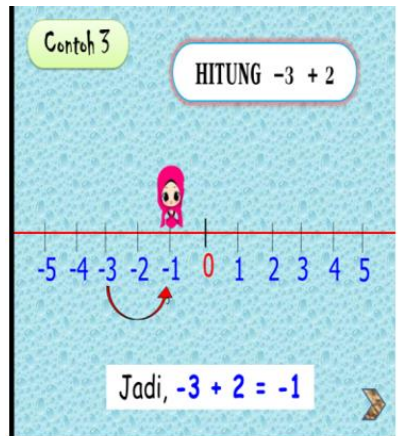

Tampilan contoh soal

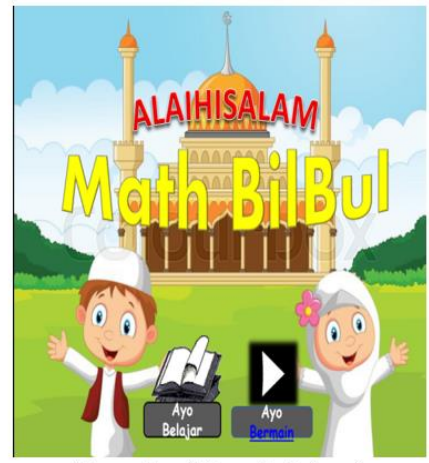

Tampilan Menu belajar dan bermain

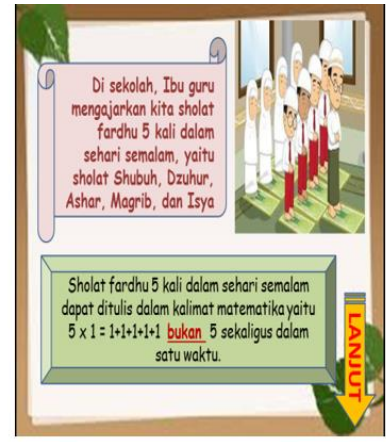

Tampilan contoh konsep perkalian dengan memadukan nilai-nilai islam

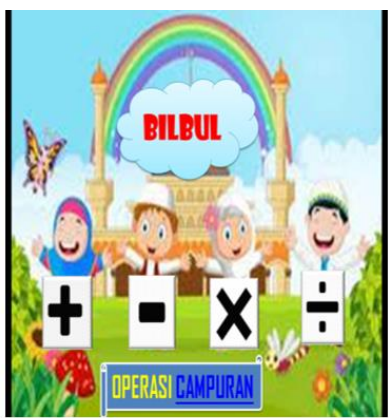

Tampilan menu operasi bilangan

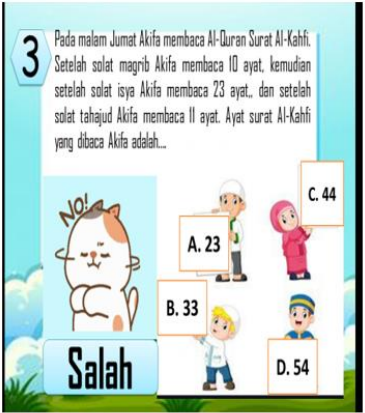

Tampilan game

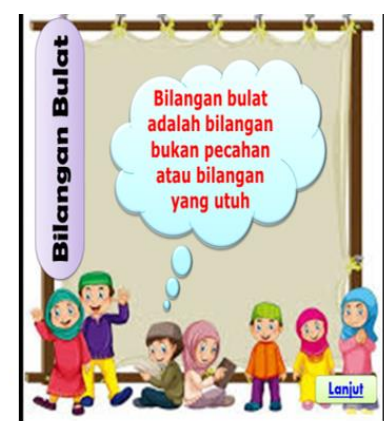

Tampilan salah satu materi

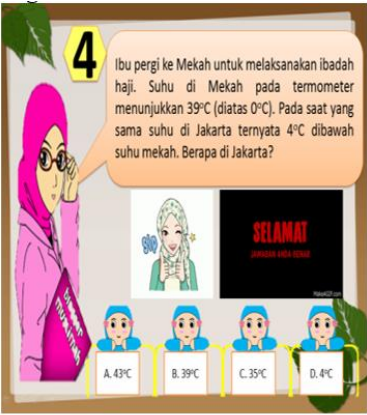

Tampilan game

FIGURE 2 / Tampilan Media Pembelajaran MathBilBul "Alaihisalam" 
Penilaian Pada Aspek Materi

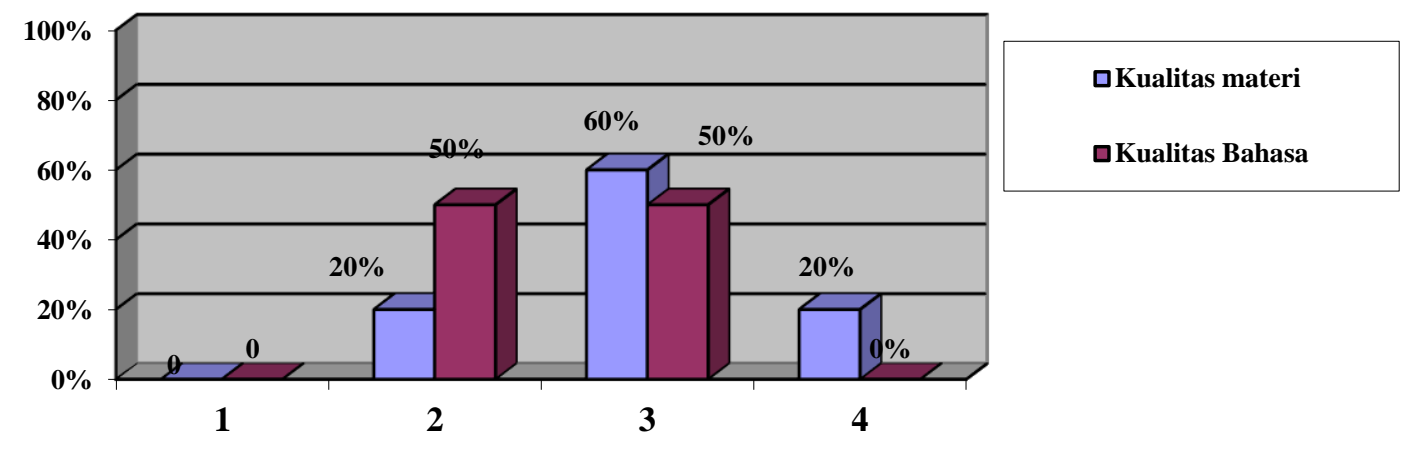

FIGURE 3 / Grafik Penilaian Aspek Materi 


\section{Penilaian Pada Aspek Keagamaan}

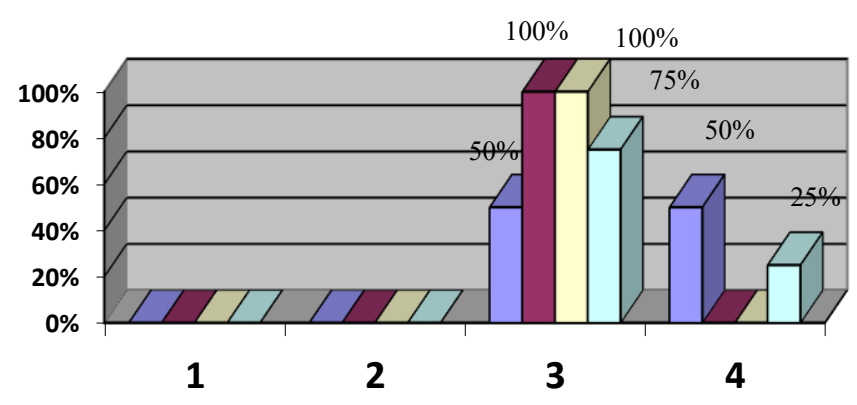

$\square$ Relevansi $\square$ Keakuratan $\square$ Konsep dasar Materi $\square$ Kesesuain Sajian dengan Tuntutan Pembelajaran yang Terpusat Pada Siswa

FIGURE 4 / Grafik Penilaian Aspek Keagamaan 


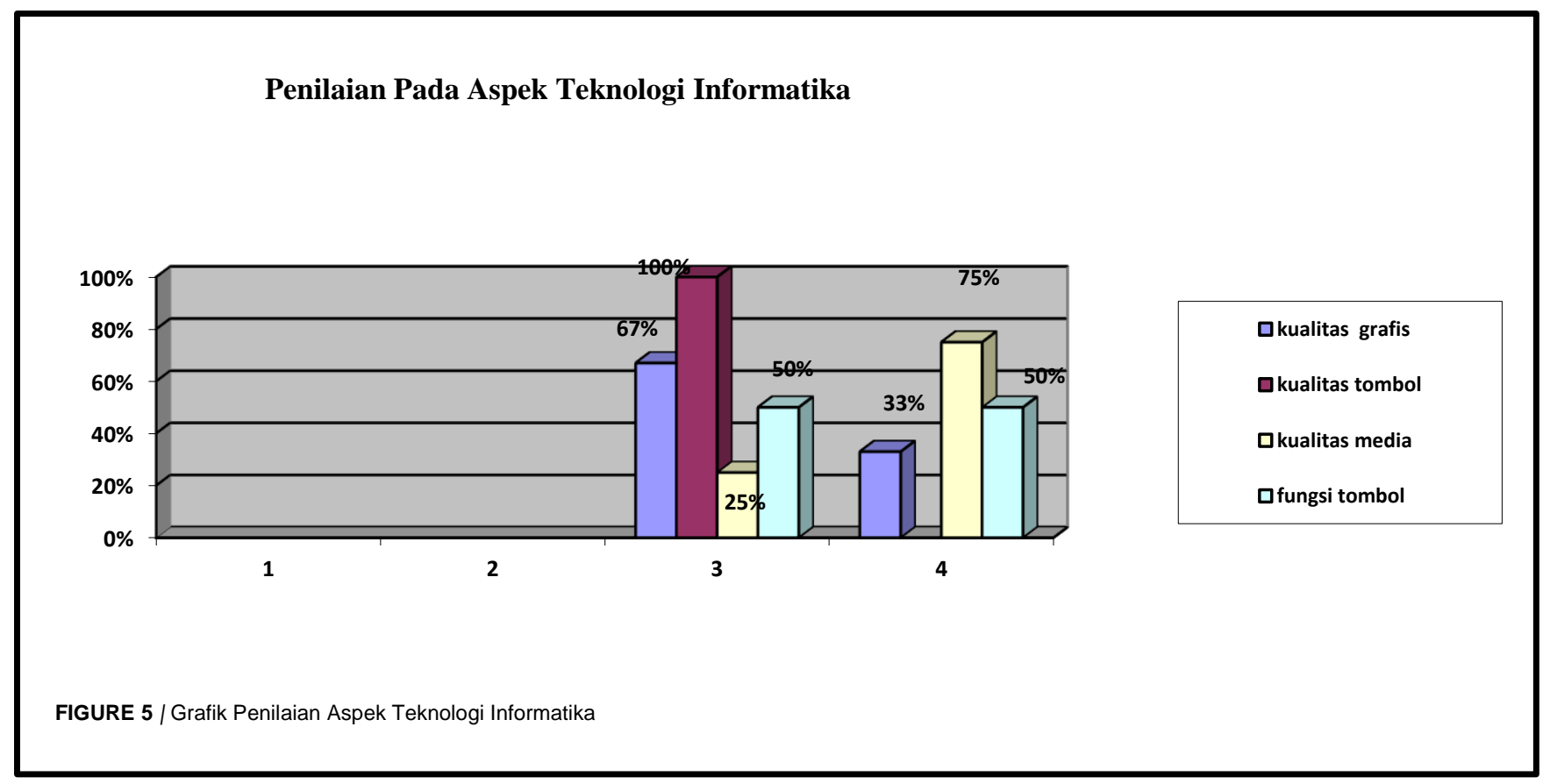

